\title{
Partial Nitrification of Wastewater from an Aminoplastic Resin Producing Factory
}

B. Fernández, A. Vilar, M. Ben, C. Kennes and M.C. Veiga

Water Science \& Technology, Vol 52 No 10-11, pp 517-524, IWA Publishing 2005

\begin{abstract}
Nitrification via nitrite was studied in two aerobic reactors treating wastewater from an aminoplastic resin producing factory at HRT varying between 1.37-1.89 and 2.45-3.63 days. Both reactors were fed with concentrations of 366, 450, 1099 and $1899 \mathrm{mg} \mathrm{N}$ $\mathrm{NH}_{4}{ }^{+} / \mathrm{L}$. In general in the reactor operated at a lower HRT, the nitritation percentage decreased from 87.2 to $21.6 \%$, while the nitratation percentage remained always lower than $2.5 \%$ (except in the last period) when the ammonium concentration was increased. This behaviour could be due to the inhibition of the ammonium and nitrite oxidation produced by high free ammonia concentrations up to $179.3 \mathrm{mg} \mathrm{N}-\mathrm{NH}_{3} / \mathrm{L}$. In the reactor operated at a higher HRT, the nitritation percentage decreased and the nitratation percentage increased from 88.6 to $39.6 \%$ and from 0.65 to $35.7 \%$, respectively, due to an increase of the dissolved oxygen concentration from 0.76 to $1.02 \mathrm{mg} \mathrm{O}_{2} / \mathrm{L}$. However, when ammonium was fed at a concentration of $1898.7 \mathrm{mg} \mathrm{N}-\mathrm{NH}_{4}{ }^{+} / \mathrm{L}$, the nitritation increased and the nitratation decreased, probably as a result of the accumulation of free ammonia up to $2.04 \mathrm{mg} \mathrm{N}-\mathrm{NH}_{3} / \mathrm{L}$, meaning that nitrite oxidizers were inhibited. Nitrite build-up was observed after each modification of ammonium concentration in the feed.
\end{abstract}

\section{Keywords}

Industrial wastewater; nitrification; via nitrite

\section{Notation}

i influent

e effluent

DO disolved oxygen

FA free ammonia FNA free nitrous acid

HRT hydraulic retention time

VSS volatile suspended solids 


\section{Introduction}

Nitrification and denitrification are well known processes used for treating nitrogen con- taining wastewater. Recently, a better effluent quality demand as well as the need of more cost-effective wastewater treatment processes have induced the research for new biological wastewater treatment systems. Although it is known that nitrite is a toxic com- pound to the aquatic organisms; nitrification and denitrification could be improved if the nitrification is stopped at the level of the intermediate nitrite. This could lead to the fol- lowing potential cost savings (Turk and Mavinic, 1987):

- the oxygen requirements during the aerobic phase are $25 \%$ lower

- carbon requirements for denitrification are $40 \%$ lower

- the nitrite reduction rate is approximately double than nitrate reduction rate.

- in anoxic phase less biomass is produced.

Nitrite oxidation rate is generally faster than the ammonium oxidation rate so that nitrite rarely accumulates in the medium. But several factors such as free ammonia, free nitrous acid, low dissolved oxygen concentration, $\mathrm{pH}$, temperature, could selectively inhibit nitrite oxidisers making possible nitrite build-up.

Both FA and FNA (non-ionized forms of ammonium and nitrite) are well-known nitrification activity inhibitors, being Nitrobacte more sensitive to the effects of these compounds. This nitratation inhibition results in nitrite accumulation. FA and FNA con- centrations in the system depend on $\mathrm{pH}$ and $\mathrm{T}$ and can be calculated by means of the following equations:

$$
\left[N-N H_{3}\right](m g / L)=\frac{\left[N-N H_{4}^{+}\right] \text {reactor }(m g / L) * 10^{p H}}{K_{b} / K_{W}+10^{p H}}
$$

$\mathrm{Kb}=$ ionization constant of ammonia in the equilibrium equation.

$\mathrm{K}_{\mathrm{W}}=$ ionization constant of water.

$\mathrm{Kb} / \mathrm{K}_{\mathrm{W}}=\mathrm{e}^{\left(6.344 / 273+7^{\prime}\right)}$

$$
\left[\mathrm{N}-\mathrm{HNO}_{2}\right](\mathrm{mg} / \mathrm{L})=\frac{\left[\mathrm{N}-\mathrm{NO}_{2}\right] \text { reactor }(\mathrm{mg} / \mathrm{L})}{\mathrm{Ka} * 10^{\mathrm{pH}}}
$$

where $\mathrm{K}_{\mathrm{a}}$ is an ionization constant of $\mathrm{HNO}_{2}$ equilibrium and can be determined by the following expression:

$\mathrm{Ka}=\mathrm{e}^{(-2.300 / 273+\mathrm{T})}$

As mentioned, FA and FNA concentrations depend on $\mathrm{pH}$, so that at high $\mathrm{pH}$ a large part of the ammonium will be present as ammonia and at low $\mathrm{pH}$ most of the nitrite will be present in the form nitrous acid.

The concentrations of FA and FNA inhibitors were estimated by many authors. Anthonisen et al. (1976) found FA inhibition of Nitrobacter and Nitrosomonas in the ranges in $0.1-1.0 \mathrm{mg} \mathrm{NH} / \mathrm{L}$ and $10-150 \mathrm{mg} \mathrm{NH}_{3} / \mathrm{L}$ respectively and FNA inhibition of nitrifying organisms at $0.22-2.88 \mathrm{mg} \mathrm{HNO}_{2} / \mathrm{L}$. This point was corroborated by Liu and Capdeville (1994). Nevertheless, other authors suggest higher threshold inhibitors concentrations. Acclimation of biomass to high ammonia concentrations is thought to be one of the factors behind this discrepancy (Turk and Mavinic, 1989).

The aim of the present work was to study the feasibility of achieving nitrification via nitrite using sludge from the aerobic chamber of an industrial wastewater treatment 
plant which was operated under overall nitrification conditions. For this purpose the dissolved oxygen was controlled and maintained at a low concentration and the free ammonia and free nitrous acid concentrations were frequently checked in the reactors.

\section{Material and methods}

\section{Wastewater and reactors}

Sludge from the aerobic chamber of a wastewater treatment plant of an amino plastic resin producing industry was inoculated in two similar laboratory scale aerobic reactors operated at HRT varying between 1.37-1.89 and 2.45-3.63 days respectively. Both reactors were fed with the same substrate. The reactor consisted in a glass vessel with a useful volume of 1.5 litre connected to a micro DCU 300 system and a settler. DO on the vessel was controlled automatically by a pO2 controller which activates the stirring, so that no pump was needed. Peristaltic pumps were employed for influent feeding and recirculation. The liquor mixture from the reactor is discharged into a settler in which sludge and supernatant are separated. Sludge is returned periodically into the reactor and maintained in the system with a minimum purge to the concentrations of solids measures and for analytical reasons.

The reactors were kept in a thermostatic chamber at $20{ }^{\circ} \mathrm{C}$, but the averaged operating temperature in the reactor was $23.1^{\circ} \mathrm{C}$.

The aerobic reactors were fed with the effluent of a laboratory scale anoxic reactor treating wastewater from an amino plastic resin producing factory. In the anoxic reactor the organic compounds were oxidized to $\mathrm{CO}_{2}$, and organic nitrogen was hydrolyzed to ammonium.

The effluent of the anoxic reactor is filtered and the ammonium concentration is adjusted by adding $\mathrm{NH}_{4} \mathrm{Cl}$ and $\left(\mathrm{NH}_{4}\right)_{2} \mathrm{SO}_{4}$. Since the alkalinity of the wastewater was not high enough to develop the nitritation, additional alkalinity was added to maintain a $\mathrm{NaHCO}_{3} / \mathrm{N}-\mathrm{NH}_{4}^{+}$ratio of 10 . Micronutrients (Eiroa et al., 2004) were added with a dilution 1:2000.

\section{Analytical methods}

Ammonium, nitrite and nitrate and $\mathrm{pH}$ in the effluent were determined three times perweek. Once a week VSS were measured in the reactor and effluent. Ammonium and nitrite were analysed in the reactor once a week in order to obtain exposure levels of the biomass to FA and FNA.

Except samples collected to measure ammonium and $\mathrm{pH}$, the rest of the samples were filtered through nylon syringe filters $(0.45 \mathrm{~mm})$ to separate the liquid and solid phases preventing further reactions. Nitrite and nitrate anions were analysed by Capillary Electrophoresis (Hewlett Packard) with a micro capillary tube of fused silica. A sodium phosphate solution was employed as the electrolyte and UV detection was undertaken at a wavelength of $214 \mathrm{~nm}$ and $450 \mathrm{~nm}$ as reference. Ammonium and DO concentrations were measured with a selective electrode. VSS and $\mathrm{pH}$ were evaluated according to Standard Methods (APHA, 1998).

\section{Calculations}

Ammoniun oxidation: $100 * \frac{\left[\mathrm{N}-\mathrm{NO}_{2}^{-}\right] \mathrm{e}-\left[\mathrm{N}-\mathrm{NO}_{2}^{-}\right] \mathrm{i}+\left[\mathrm{N}-\mathrm{NO}_{3}^{-}\right] \mathrm{e}-\left[\mathrm{N}-\mathrm{NO}_{3}^{-}\right] \mathrm{i}}{\left[\mathrm{N}-\mathrm{NH}_{4}^{+}\right] \mathrm{i}}$

Nitrite accumulation: $100 * \frac{\left[\mathrm{N}-\mathrm{NO}_{2}^{-}\right] e-\left[\mathrm{N}-\mathrm{NO}_{2}^{-}\right] \mathrm{i}}{\left[\mathrm{N}-\mathrm{NO}_{2}^{-}\right] e-\left[\mathrm{N}-\mathrm{NO}_{2}^{-}\right] \mathrm{i}+\left[\mathrm{N}-\mathrm{NO}_{3}^{-}\right] e-\left[\mathrm{N}-\mathrm{NO}_{3}^{-}\right] \mathrm{i}}$ 
Nitritation percentage: $100 * \frac{\left[\mathrm{N}-\mathrm{NO}_{2}^{-}\right] \mathrm{e}-\left[\mathrm{N}-\mathrm{NO}_{2}^{-}\right] \mathrm{i}}{\left[\mathrm{N}-\mathrm{NH}_{4}^{+}\right] \mathrm{i}}$

Nitratation percentage: $100 * \frac{\left[\mathrm{N}-\mathrm{NO}_{3}^{-}\right] \mathrm{e}-\left[\mathrm{N}-\mathrm{NO}_{3}^{-}\right] \mathrm{i}}{\left[\mathrm{N}-\mathrm{NH}_{4}^{+}\right] \mathrm{i}}$

\section{Results and discussion}

During the experimental period different nitrogen loading rates (NLR) were applied. For reactor $\mathrm{R} 1$, operated at a HRT close to $1.7 \mathrm{~d}$, the nitrogen loading rate ranged from 0.254 to $1.164 \mathrm{~g} \mathrm{~N}-\mathrm{NH}_{4}^{+} / \mathrm{L} \cdot \mathrm{d}$ and for reactor R2, operated at a HRT close to $3.0 \mathrm{~d}$, the nitrogen loading rate ranged from 0.108 to $0.645 \mathrm{~g} \mathrm{~N}-\mathrm{NH}_{4}^{+} / \mathrm{L} \cdot \mathrm{d}$.

Table 1 summarises the operational conditions maintained in reactors R1 and R2 during the experimental period. DO was checked and maintained close to $0.8 \mathrm{mg} \mathrm{O} / \mathrm{L}$. Previous assays showed this concentration was the optimum level to achieve nitrification via nitrite. To try to enhance ammonium oxidation in R1, DO concentration was increased to $2.54 \mathrm{mg} \mathrm{O} 2 / \mathrm{L}$ in the last period (E). In R2, DO level was decreased to $0.43 \mathrm{mg} \mathrm{O}_{2} / \mathrm{L}$ in the period $\mathrm{E}$ to avoid nitrite oxidation to nitrate.

Table 1 Operational conditions of reactors R1 and R2

\begin{tabular}{|c|c|c|c|c|c|c|}
\hline & \multicolumn{5}{|c|}{$\mathrm{N}-\mathrm{NH}_{4}^{+}(\mathrm{mg} / \mathrm{L})$} \\
\hline & & (A) 450 & (B) 366 & (C) 1099 & (D) 1899 & (E) 1899 \\
\hline \multirow[t]{3}{*}{$\overline{\mathrm{R} 1}$} & Operation day & $17-39$ & $63-83$ & $103-122$ & $123-152$ & $153-222$ \\
\hline & $\operatorname{NLR}\left(\mathrm{kg} / \mathrm{m}^{3} \cdot \mathrm{d}\right)$ & 0.336 & 0.254 & 0.753 & 1.0806 & 1.164 \\
\hline & $\mathrm{DO}_{\mathrm{r}}\left(\mathrm{mg} \mathrm{O}_{2} / \mathrm{L}\right)$ & 0.82 & 0.83 & 0.65 & 0.63 & 2.54 \\
\hline \multirow[t]{4}{*}{$\mathrm{R} 2$} & Operation day & $6-28$ & $52-72$ & $92-113$ & $114-140$ & $141-212$ \\
\hline & $\mathrm{HRT}(\mathrm{d})$ & 3.63 & 3.18 & 2.45 & 2.97 & 3.31 \\
\hline & $\operatorname{NLR}\left(\mathrm{kg} / \mathrm{m}^{3} \cdot \mathrm{d}\right)$ & 0.126 & 0.108 & 0.504 & 0.645 & 0.631 \\
\hline & $\mathrm{DO}_{\mathrm{r}}\left(\mathrm{mgO}_{2} / \mathrm{L}\right)$ & 0.76 & 0.89 & 1.02 & 0.99 & 0.43 \\
\hline
\end{tabular}

Time course analysis

Both reactors were fed with concentrations of 366, 450, 1099 and $1899 \mathrm{mg} \mathrm{N}-\mathrm{NH}_{4}^{+} / \mathrm{L}$.

In R1, during periods A-D the DO concentration was kept between 0.63 and $0.83 \mathrm{mg}$ $\mathrm{O}_{2} / \mathrm{L}$ and the ammonium concentration in the feed was varied between 366 and 1899 mg N-NH$H_{4}^{+} / \mathrm{L}$. Ammonium oxidation decreased from 90.2 to $20.0 \%$ with a simultaneous FA accumulation from 0.15 to $179.34 \mathrm{mg} \mathrm{N}-\mathrm{NH}_{3} / \mathrm{L}$. The nitritation percentage decreased from 87.2 to $21.6 \%$, while the nitratation percentage remained always below $2.9 \%$. The nitrite accumulation was always higher than $76.9 \%$. As shown in Figure 1, in period A an ammonium oxidation of $90.2 \%$ and a nitrite accumulation of $99.8 \%$ were obtained with a FA concentration of $0.15 \mathrm{mg} \mathrm{N}-\mathrm{NH}_{3} / \mathrm{L}$, which was not inhibitory to ammonium oxidizers but it was inhibitory to nitrite oxidizers. However, in period $\mathrm{B}$ the FA concentration reached an average of $5.8 \mathrm{mg} \mathrm{N}-\mathrm{NH}_{3} / \mathrm{L}$ which was inhibitory to both ammonium and nitrite oxidizers, resulting in an ammonium oxidation of $39.7 \%$ and in a nitrite accumulation of $97.9 \%$. 

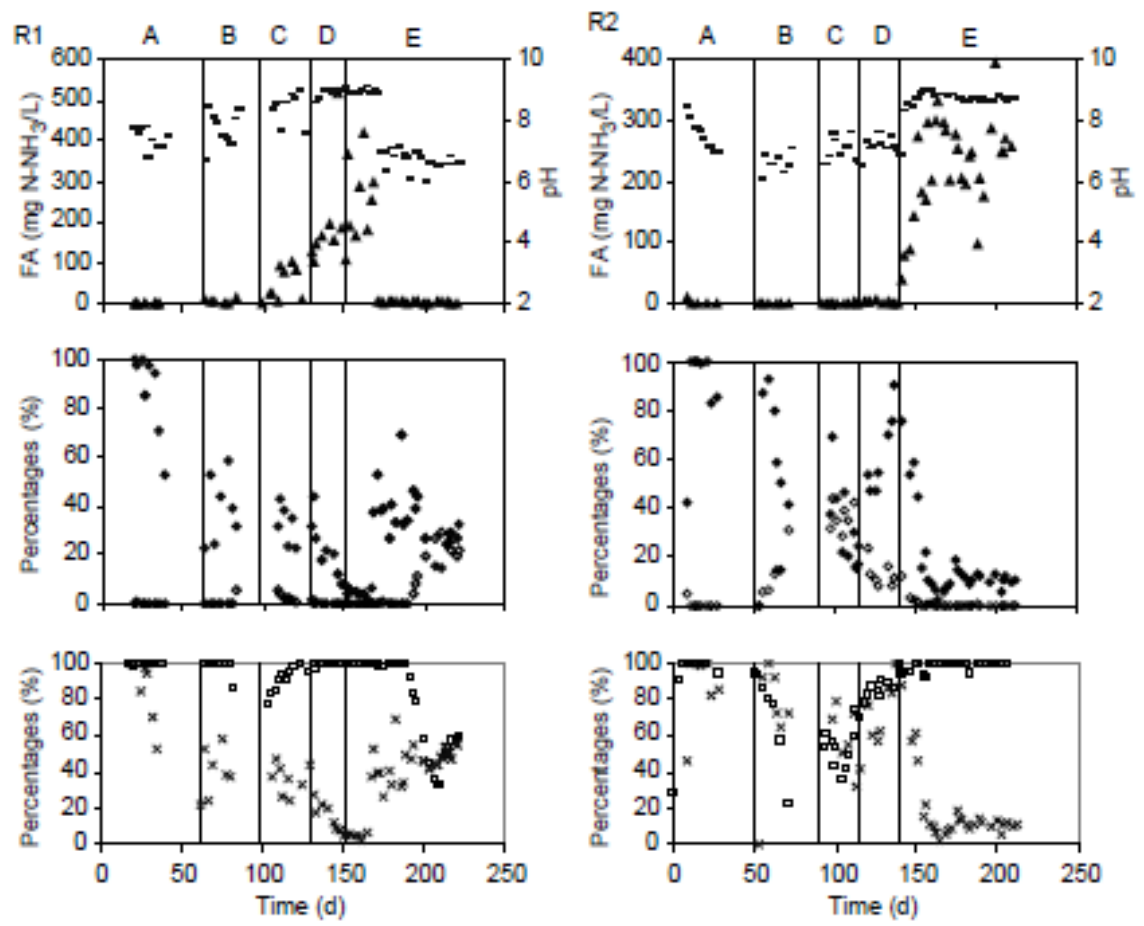

Figure 1 Evolution of free ammoria $(\mathbf{\Lambda})$ and $\mathrm{pH}(\mathbf{\boldsymbol { D }})$; nitritation $(\bullet)$ and nitratation $(0)$ percentages; and ammorium coxidation $(X)$ and nitrite accumulation $(\square)$ in R1 and R2. The ammonium concentration in the feed at the different periods was: 450 (A), $366(B), 1099(\mathrm{C}), 1899(\mathrm{D})$ and $1899(\mathrm{E}) \mathrm{mg} \mathrm{N}-\mathrm{NH}_{4}^{+} / \mathrm{L}$

In period $\mathrm{C}$ the average ammonia concentration increased to $58 \mathrm{mg} \mathrm{NNH}_{3} / \mathrm{L}$, being the ammonium oxidation of $35.3 \%$, close to that obtained in period B. During period D the FA concentration rose from 125 to $187 \mathrm{mg} \mathrm{N}-\mathrm{NH}_{3} / \mathrm{L}$, and an almost complete inhibition of ammonium oxidizers was observed, reaching values of ammonium oxidation close to 8\%. In both periods $\mathrm{C}$ and $\mathrm{D}$, the DO concentration was similar around $0.64 \mathrm{mg} \mathrm{O}_{2} / \mathrm{L}$. However, this DO concentration was not a limiting factor since the nitrite concentration in period $\mathrm{D}$ averaged $399 \mathrm{mg} \mathrm{N}-\mathrm{NO}_{2} / \mathrm{L}$ with a maximum close to $680 \mathrm{mg} \mathrm{N}-\mathrm{NO}_{2} / \mathrm{L}$ and higher than in period $\mathrm{C}$ (302 mg N-NO2/L). The increase of ammonium concentration in the feed together with excess of alkalinity caused an increase of $\mathrm{pH}$ and FA resulting in a higher inhibition of nitritation. In period $\mathrm{E}$, the ammonium concentration in the feed was the same as in period D (1899 $\left.\mathrm{mg} \mathrm{N}-\mathrm{NH}_{4}^{+} / \mathrm{L}\right)$. In order to improve the ammonium oxidation DO concentration was increased from 0.64 to $2.54 \mathrm{mg} \mathrm{O}_{2} / \mathrm{L}$. At the beginning of this period, the alkalinity in the feed was $13170 \mathrm{mg} \mathrm{CaCO}_{3} / \mathrm{L}$ and the reactor $\mathrm{pH}$ was close to 8.7 with an average FA concentration increase of $257.7 \mathrm{mg} \mathrm{N}-\mathrm{NH}_{3} / \mathrm{L}$ being the ammonium oxidation close to $9.3 \%$. Hence, the alkalinity was decreased in the feed down to a $\mathrm{NaHCO} / \mathrm{N}-\mathrm{NH}_{4}^{+}$ratio equal to 6, leading to a decrease of the $\mathrm{pH}$ to 6.77 and a decrease of FA concentration to $3.9 \mathrm{mg} \mathrm{N}-\mathrm{NH}_{3} / \mathrm{L}$. Under these conditions ammonium oxidizers recovered their activity, and the nitritation percentage increased to $41.2 \%$, with nitrite accumulation of $98.8 \%$. However at the end of the period an increase in nitrite oxidation took place along with a decrease of FA concentrations with a final concentration of $3.0 \mathrm{mg} \mathrm{N}-\mathrm{NH}_{3} / \mathrm{L}$. In $\mathrm{R} 2$ during periods $\mathrm{A}, \mathrm{B}$ and $\mathrm{C}$, the $\mathrm{DO}$ concentration increased from 0.76 to $1.02 \mathrm{mg} \mathrm{O}_{2} / \mathrm{L}$ and the nitrite accumulation decreased from 90.9 to $44 \%$. So, nitritation decreased from 88.6 to $39.6 \%$ while nitratation increased from 0.6 to $35.6 \%$. According to Ruiz et al. (2003) this behaviour can be due to the DO concentration. They obtained a maximum nitrite accumulation of $65 \%$ at $0.7 \mathrm{mg} \mathrm{O}_{2} / \mathrm{L}$, but at higher DO concentrations nitrite was oxided to nitrate. In 
addition, the FA concentration decreased from 1.72 to less than $0.4 \mathrm{mg} \mathrm{N}-\mathrm{NH}_{3} / \mathrm{L}$. With regard to ammonium oxidation, in spite of remaining higher than $73.3 \%$, a slight decrease was observed simultaneous to an increase of the nitrogen loading rate from 0.108 to $0.504 \mathrm{~g} \mathrm{~N}-\mathrm{NH}_{4}^{+} / \mathrm{L} \cdot \mathrm{d}$. This tendency was also found by Gupta and Sharma (1996) who observed that the nitrogen removal efficiency decreased when the nitrogen loading rate increased. In period D, the DO concentration was close to the DO concentration of period $\mathrm{C}\left(1.02 \mathrm{mg} \mathrm{O}_{2} / \mathrm{L}\right)$ and the nitrogen loading rate was only increased 1.25 times (this varied between $0.504-0.645 \mathrm{Kg} / \mathrm{m}^{3} \cdot \mathrm{d}$ ). Under these conditions ammonium oxidation was approximately the same, but nitritation percentage raised to $50.8 \%$ and nitratation percentage went down to $16.7 \%$. Possibly this could be related to an increase in the FA concentration to $2.04 \mathrm{mg} \mathrm{N}-\mathrm{NH}_{3} / \mathrm{L}$, meaning that nitrite oxidizers were inhibited by free ammonia. However, ammonium oxidizers were not inhibited by this free ammonia concentration. In period $\mathrm{E}$, in order to achieve a higher nitritation efficiency a DO concentration of $0.43 \mathrm{mg} \mathrm{O}_{2} / \mathrm{L}$ was tested, but the oxygen became a limiting factor. Consequently the ammonium oxidation decreased to $18.4 \%$.

In most of the periods and for both of the reactors nitrite build-up was observed after each modification of the ammonium concentration in the feed, probably associated to a variation of the rest of the parameters involved in this process, as $\mathrm{pH}, \mathrm{DO} \ldots$ High nitrite concentrations were reached in both reactors, being the highest nitrite concentrations $1597 \mathrm{mg} \mathrm{N}-\mathrm{NO}_{2 / \mathrm{L}}$ in R2 (period D) and $1194 \mathrm{mg} \mathrm{N}-\mathrm{NO}_{2} / \mathrm{L}$ in R1 (period E).

Nitratation percentages were very different in both reactors. The highest nitrate percentages were obtained in R2 while highest nitrite accumulations were attained in R1. This difference can be due not only to the free ammonia and DO found in the mediumbut also to the HRT used. Lower nitratation percentages obtained for lower HRT wich is probably associated to the lower contact time between bacteria and nitrogen substrate. Ruiz et al. (2003) working with a SBR reported that at short aerobic phases nitrite accumulation was greater than at long aerobic phases, however, nitrogen removal was more efficient in long aerobic phases. The DO and the medium free ammonia are important parameters for nitrite build-up.

\section{DO influence}

DO is known to have an important effect on the activity and settleability of the sludge (Dangcong et al., 2001). Generally, in overall nitrification process it is recommended to keep DO levels higher than 2-3mg O2/L to obtain nitrate as final product. Several authors observed that working with lower levels they were able to stop the process at the intermediate nitrite (Ruiz et al., 2003; Garrido et al., 1997).

As shown in Table 1, the DO concentration in R1 decreased during the course of the experimental period except in the last assay where it was increased to $2.54 \mathrm{mg} \mathrm{O}_{2} / \mathrm{L}$.

As can be seen in Figure 2, in R2, the DO concentration ranged from 0.76 to $1.02 \mathrm{mg}$ $\mathrm{O}_{2} / \mathrm{L}$ being in the last period decreased to $0.43 \mathrm{mg} \mathrm{O} / \mathrm{L}$. A nitritation percentage increase was noticed with a DO concentration decrease up to reach a value of $0.76 \mathrm{mg}$ $\mathrm{O}_{2} / \mathrm{L}$, at which a maximum nitritation percentage of $88.6 \%$ was attained. At DO concentration of $0.43 \mathrm{mg} \mathrm{O}_{2} / \mathrm{L}$ nitritation and ammonium oxidation felt down to $17.6 \%$ and $18.4 \%$ respectively. This indicates that the DO concentration is a limiting factor in nitrification, which was also reported by Yoo et al. (1999) who observed a decrease or suppression of nitrification at low DO concentrations. At this low DO concentration a decrease of ammonium oxidation and alkalinity consumption resulting in a FA 
concentration increase. The FA concentration reached in this period was high enough to inhibit both the nitritation and nitratation processes. The nitratation percentage increased from 0.6 to $35.6 \%$ with the DO, as can be seen in Figure 2.

The results obtained in this research are in agreement with the results obtained by Ruiz et al. (2003) who observed an increased nitrite build-up and the same ammonium consumption at DO concentrations ranging between $1.7-0.7 \mathrm{mg} \mathrm{O}_{2} / \mathrm{L}$. Both nitrite buildup and ammonia oxidation decrease appeared when the DO concentration was below $0.5 \mathrm{mg} \mathrm{O}_{2} / \mathrm{L}$. Nitrite build-up started at concentrations below $1.7 \mathrm{mg} \mathrm{O}_{2} / \mathrm{L}$, reaching a maximum nitrite build-up at $0.7 \mathrm{mg} \mathrm{O} 2 / \mathrm{L}$, being ammonium completely oxidized.

In $\mathrm{R} 1$ a nitritation percentage higher than $21.6 \%$ was obtained at values of DO from 0.63 to $2.54 \mathrm{mg} \mathrm{O}_{2} / \mathrm{L}$. A maximum nitritation percentage of $87.2 \%$ and ammonium oxidation of $90.2 \%$ were achieved at $0.82 \mathrm{mg} \mathrm{O} / \mathrm{L}$. Nitritation percentages of $32.4 \%$ and $21.6 \%$ were attained at DO concentrations of 0.65 and $0.63 \mathrm{mg} \mathrm{O}_{2} / \mathrm{L}$ respectively.
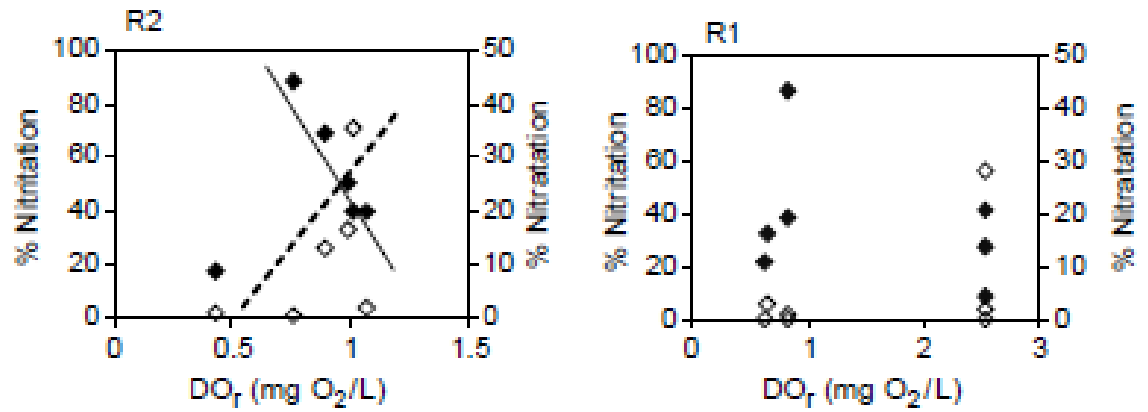

Figure 2 Nitritation $(\bullet)$ and nitratation $(\diamond)$ percentages of R1 and R2 versus average DO levels of different operational periods for reactors R2 and R1

However, at DO concentrations of $0.83 \mathrm{mg} \mathrm{O}_{2} / \mathrm{L}$ a nitritation percentage of $38.9 \%$ was also observed, corresponding to a different operation period of the reactor. At a DO concentration of $2.54 \mathrm{mg} \mathrm{O}_{2} / \mathrm{L}$, wide variations of nitritation (9.3-41.2\%) and nitratation percentages (0-20.9\%) were obtained, probably due to variations in FA concentration (258-2.3 mg N-NH$/ \mathrm{L}$ ). In both periods $\mathrm{D}$ and $\mathrm{E}$ the nitritation percentages obtained were always lower than at a DO concentration of $0.82 \mathrm{mg} \mathrm{O}_{2} / \mathrm{L}$, which may indicate that other inhibitory factors must be considered. The nitratation percentage was maintained below $2.9 \%$ except for a DO concentration of $2.54 \mathrm{mg} \mathrm{O}_{2} / \mathrm{L}$ in which the nitratation percentage increased from 0 to $20.9 \%$. With regard to ammonium oxidation, the tendency expected would be to obtain low ammonium oxidation at concentration below $0.82 \mathrm{mg} \mathrm{O}_{2} / \mathrm{L}$ and higher oxidation at higher concentrations than $0.82 \mathrm{mg} \mathrm{O} / \mathrm{L}$. However, in this work at DO concentrations higher than $0.82 \mathrm{mg} \mathrm{O}_{2} / \mathrm{L}$ we observed a decrease of ammonium oxidation, which could indicate that DO is not sole factor to take into account.

Analysing periods (D) and (E) in which ammonium concentration in the feed was close to $1899 \mathrm{mg} \mathrm{N}-\mathrm{NH}_{4} / \mathrm{L}$ and DO concentration was modified, it was observed that in R1 when the DO concentration was increased from 0.63 to $2.54 \mathrm{mg} \mathrm{O}_{2} / \mathrm{L}$, the percentage ammonium oxidation increased from 20.0 to $49.0 \%$ but nitrite accumulation decreased from 99.3 to $53.7 \%$. In R2 when DO concentration was decreased from 0.99 to 0.43 $\mathrm{mgO}_{2} / \mathrm{L}$ ammonium oxidation dropped from 67.4 to $18.4 \%$, but nitrite accumulation 
rose from 73.8 to $98.4 \%$. Hence, limiting DO concentration was the main factor in order to attain nitrification via nitrite.

\section{FA and FNA effects}

As shown in Figure 3, in both reactors a FA concentration increase caused a nitritation percentage decrease. With regard to nitratation percentage, in R1 for periods A-D it was lower than $2.9 \%$ at FA concentrations ranging from 0.15 to $179.34 \mathrm{mg} \mathrm{N}-\mathrm{NH} 3 / \mathrm{L}$. At the beginning of period $\mathrm{E}$ a nitritation percentage of $5.9 \%$ and nitratation percentage of $0 \%$ were obtained when the average FA concentration in the reactor was $258 \mathrm{mg} \mathrm{N}-\mathrm{NH} 3 / \mathrm{L}$. At the end of the period $\mathrm{E}$ the FA concentration decrease to $2.3 \mathrm{mg} \mathrm{N}-\mathrm{NH} 3 / \mathrm{L}$ leading to an increase of nitritation percentage to $28 \%$. Due to the low FA concentration and high DO concentration, a nitratation percentage of $20.9 \%$ was obtained. It is believed that DO alleviate FA inhibitor effect, so discrepancies in FA inhibitors concentrations reported by different authors might be due to this fact (Turk and Mavinic, 1989). On the order hand, Suthersand and Ganczarczyk (1986) working at DO concentrations between 6-8 $\mathrm{mg} \mathrm{O}_{2} / \mathrm{L}$ noticed that Nitrobacter before continuously acclimatizing was able to tolerate inhibitory concentrations of FA equal to $2.5 \mathrm{mg} \mathrm{N}-\mathrm{NH} 3 / \mathrm{L}$ at which it was previously inhibited. In R2 the FA concentrations in periods B, C and D were lower than those found in R1, obtaining higher nitratation percentages than in R1. In both reactors FNA inhibition of nitrifying organisms was not observed in spite of reaching FNA concentrations in the range proposed as inhibitory by Anthonisen et al. (1976).
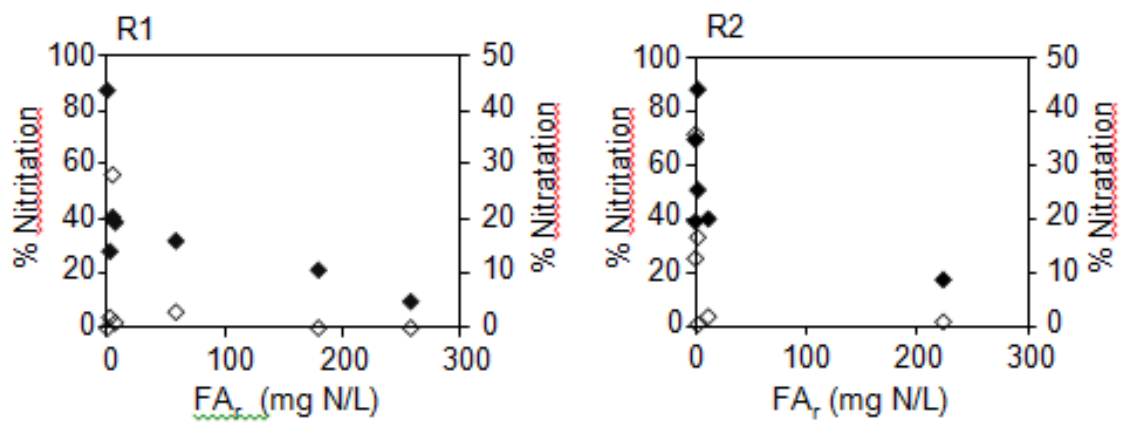

Figure 3 Nitritation ( $\bullet$ and nitratation $(\bullet)$ bercentages, of R1 and R2 versus median FA levels of different operational periods

\section{Conclusions}

Differences in DO concentration, FA concentration, nitrogen loading rate and HRT could explain different nitritation, nitratation and ammonium oxidation percentages obtained in this research.

An optimum DO concentration of $0.8 \mathrm{mg} \mathrm{O}_{2} / \mathrm{L}$ led to the maximum nitritation percentage, higher DO concentrations might cause a decrease in nitritation and an increase in nitratation percentages. A deviation in this tendency might indicate that other factors such as an increased nitrogen loading rate and FA might be influencing the nitrification.

A FA concentration increase provoked a nitritation percentage decrease. Different nitratation percentages obtained for R1 and R2 could be explained with the different FA 
concentration present. FA concentrations higher than $2.04 \mathrm{mg}$ N-NH3/L were inhibitory.

At high HRT the reactor showed higher nitratation percentages probably associated to the higher contact time between bacteria and substrate.

\section{Acknowledgements}

The present research was funded by the Spanish Ministry of Science and Technology, projects REN2000-0218-P4-0 and PPQ2002-02882. B. Ferna'ndez is also grateful to the Xunta de Galicia for a Ph.D. fellowship.

\section{References}

Anthonisen, A.C., Loehr, R.C., Prakasam, T.B.S. and Srinath, E.G. (1976). Inhibition of nitrification by ammonia an nitrous acid. J. Wat. Pollut. Cont. Fed, 48(5), 835-852.

APHA (1998). Standard Methods for the Examination of Water and Wastewater, 20th ed., Washington DC, USA.

Dangcong, P., Bernet, N., Delgenes, J.-P. and Moletta, R. (2001). Simultaneous organic carbon and nitrogen removal in an SBR controlled at low dissolved oxygen concentration. J. Chem. Technol. Biotechnol., 76, 553-558.

Eiroa, M., Kennes, C. and Veiga, C.M. (2004). Formaldehyde biodegradation and its inhibitory effect on nitrification. J. Chem. Technol. Biotechnol., 79, 499-504.

Garrido, J.M., Van Bethum, W.A.J., Van Loodsdretcht, M.C.M. and Heijnen, J.J. (1997). Influence of dissolved oxygen concentration on nitrite accumulation in a biofilm airlift suspension reactor. Biotechnol. Bioeng., 53(2), 168-178.

Gupta, S.K. and Sharma, R. (1996). Biological oxidation of high strength nitrogenous wastewater. Wat. Res., 30(3), 593-600.

Liu, Y. and Capdeville, B. (1994). Some observations on free ammonia inhibition to nitrobacter in nitrifying biofilm reactor. Biotechnol. Lett., 16(3), 309-314.

Ruiz, G., Jeison, D. and Chamy, R. (2003). Nitrification with high nitrite accumulation for the treatment of wastewater with high ammonia concentration. Wat. Res., 37, 13711377.

Suthersand, S. and Ganczarczyk, J.J. (1986). Inhibition of nitrite oxidation during nitrification some observations. Water. Pollut. Res. J. Canada, 21(2), 257-266.

Turk, O. and Mavinic, D.S. (1987). Benefits of using selective inhibition to remove nitrogen from highly nitrogenous wastes. Environmental Technology Letters, 8, 419426.

Turk, O. and Mavinic, D.S. (1989). Stability of nitrite build-up in an activated sludge system. J. Wat. Pollut.Cont. Fed, 61, 1440-1447.

Yoo, H., Ahn, K.-H., Lee, H.-J., Lee, K.-H., Kwak, Y.-J. and Song, K.-G. (1999). Nitrogen removal from synthetic wastewater by simultaneous nitrification and denitrification (SND) via nitrite in an intermittently-aerated reactor. Wat. Res., 33(1), 145-154. 